\title{
Synthesis and optical properties of biphenylene ethynylene co-polymers and their model compounds
}

\author{
OKHIL K NAG ${ }^{\mathrm{a}}$, KAZI M ANIS-UL-HAQUE ${ }^{\mathrm{a}}$, DIPEN DEBNATH ${ }^{\mathrm{a}}$, ROCKSHANA BEGUM ${ }^{\mathrm{a}}$, \\ MUHAMMAD YOUNUS ${ }^{\mathrm{a}, *}$, NAZIA CHAWDHURY ${ }^{\mathrm{b}}$, GABRIELE KOCIOK-KÖHN ${ }^{\mathrm{c}}$ and \\ PAUL R RAITHBY ${ }^{\mathrm{C}}$ \\ ${ }^{a}$ Department of Chemistry, Shahjalal University of Science and Technology, Sylhet 3114, Bangladesh \\ ${ }^{b}$ Department of Physics, Shahjalal University of Science and Technology, Sylhet 3114, Bangladesh \\ ${ }^{c}$ Department of Chemistry, University of Bath, Bath BA2 7AY, UK \\ e-mail: myounus_che@yahoo.com; myounus-che@sust.edu
}

MS received 25 December 2013; revised 20 July 2014; accepted 21 July 2014

\begin{abstract}
A new series of biphenylene ethynylene co-polymers, poly(2,5-dialkoxy-4-phenyleneethynylene4,4-biphenyleneethynylene)s of the general formula [-C $\left.\equiv \mathrm{C}-4-\mathrm{C}_{6} \mathrm{H}_{4}-\mathrm{C}_{6} \mathrm{H}_{4}-4-\mathrm{C} \equiv \mathrm{C}-\mathrm{C}_{6} \mathrm{H}_{2}(2,5-\mathrm{OR})_{2}-\right]_{\mathrm{n}}$ $\left(\mathrm{R}=\mathrm{C}_{4} \mathrm{H}_{9} \mathbf{P 1}, \mathrm{C}_{8} \mathrm{H}_{17} \mathbf{P 2}\right)$ has been synthesized using a palladium/copper catalyzed coupling reaction between $\mathrm{HC} \equiv \mathrm{C}-4-\mathrm{C}_{6} \mathrm{H}_{4}-\mathrm{C}_{6} \mathrm{H}_{4}-4-\mathrm{C} \equiv \mathrm{C}-\mathrm{H}$ and $\mathrm{IC}_{6} \mathrm{H}_{2}(2,5-\mathrm{OR})_{2} \mathrm{I}$. The new co-polymer $\left[-\mathrm{C} \equiv \mathrm{C}_{-} \mathrm{C}_{6} \mathrm{H}_{2}\left(2,5-\mathrm{OC}_{8} \mathrm{H}_{17}\right)_{2}-\right.$ $\left.\mathrm{C} \equiv \mathrm{C}-\mathrm{C}_{6} \mathrm{H}_{2}\left(2,5-\mathrm{OC}_{4} \mathrm{H}_{9}\right)_{2}-\right]_{\mathrm{n}}$ P5 has also been formed where different alkoxy substituents are present on alternate arene rings in the same polymer backbone. All the polymers were characterized by $\mathrm{IR},{ }^{1} \mathrm{H}$ and ${ }^{13} \mathrm{C}$ NMR spectroscopy and by GPC. The model compounds $\mathrm{C}_{6} \mathrm{H}_{5}-4-\mathrm{C}_{6} \mathrm{H}_{4}-\mathrm{C} \equiv \mathrm{C}_{-} \mathrm{C}_{6} \mathrm{H}_{2}(2,5-\mathrm{OR})_{2}-4-\mathrm{C}_{6} \mathrm{H}_{4}-$ $\mathrm{C}_{6} \mathrm{H}_{5}\left(\mathrm{R}=\mathrm{C}_{4} \mathrm{H}_{9}\right.$ M1, $\mathrm{C}_{8} \mathrm{H}_{17}$ M2) have also been prepared by the reaction between $\mathrm{C}_{6} \mathrm{H}_{5}-4-\mathrm{C}_{6} \mathrm{H}_{4}-\mathrm{C} \equiv \mathrm{CH}$ and $\mathrm{IC}_{6} \mathrm{H}_{2}(2,5-\mathrm{OR})_{2} \mathrm{I}$. Single crystal X-ray structures of M1, M2 and $\mathrm{Me}_{3} \mathrm{Si}-\mathrm{C} \equiv \mathrm{C}-4-\mathrm{C}_{6} \mathrm{H}_{4}-\mathrm{C}_{6} \mathrm{H}_{4}-4-\mathrm{C} \equiv \mathrm{C}-$ $\mathrm{SiMe}_{3}$ were determined with a view to obtain a better understanding of the molecular and intermolecular interactions in the solid state which has been used to explain the optical properties of the polymers derived from them. The absorption and photoluminescence spectra of the polymers, P1, P2 and P5 showed that the lowest energy band is blue shifted due to the introduction of biphenylene fragments into the alkoxy substituted poly(ethynylenephenylene)s.
\end{abstract}

Keywords. Alkoxy substituted poly(ethynylenephenylene); co-polymer; photoluminescence; sonogashira cross-coupling reaction; x-ray crystallography.

\section{Introduction}

There has been a growing interest in the synthesis and exploration of the structure-property relationship of $\pi$ conjugated polymers (CPs) due to their application in organic electronics ${ }^{1,2}$ and fluorescence-based sensing. ${ }^{3}$ These polymers have started to find use in making light emitting diodes (LEDs), ${ }^{4,5}$ liquid crystals,,${ }^{6,7}$ photovoltaic cells, ${ }^{8}$ and as sensors for metal ions, ${ }^{9}$ warfare agents, ${ }^{10}$ bacteria and biomolecules. ${ }^{3}$ Since its discovery, extensive studies on the $\pi$-conjugated polymers based on polythiophene, poly ( $p$-phenylene), poly(phenylenevinylene), polyfluorene and poly(aryleneethynylene) (PAEs) have been performed for their potential applications. ${ }^{3}$ PAEs are wide-gap semiconductors which contain a rigid-rod backbone, ${ }^{11}$ and can have fluorescence quantum yields of up to unity in solution. ${ }^{12}$ Semiconducting nature of PAEs has

\footnotetext{
*For correspondence
}

generated interest in developing electroluminescent polymers for device applications. ${ }^{13,14}$ PAEs also have been used to demonstrate in biosensing applications in homogeneous aqueous solution. ${ }^{15}$ The watersolubility of PAEs can be achieved by introducing electrolytic functionalities such as quaternary ammonium, sulphonate, carboxylate and phosphonate group into the side chain. ${ }^{15}$ However, the widespread uses of PAEs are impaired by synthetic difficulties and poor solubility in common organic solvents that limit their characterizations and applications as active materials in organic electronics. PAEs have been made solution processable by adding alkyl or alkoxy side chains to the aromatic fragment of the polymers so that the optoelectronic properties can be studied either in solution or in spin-cast thin films. ${ }^{13}$ Furthermore, it is possible to fine-tune the optoelectronic (HOMO-LUMO energy level) properties, morphology, intra- or inter-chain $\pi$ $\pi$ stacking of the CPs in solid and solution state by adding alkyl or alkoxy side-chain on the polymer 
backbone. ${ }^{2}$ Better understanding and optimization of the morphology of CPs in solid or solution state are always important for their proper utilization in applications. Thus, a popular research theme has focused on exploring and tuning properties of the $\pi$-conjugated molecules by rational design on the molecular level.

The palladium-catalyzed coupling ${ }^{16}$ between terminal acetylenes and aromatic iodides or bromides in amine solvent is the most widely used method for the synthesis of PAEs-type of CPs. ${ }^{17-21}$ Alkyne metathesis is recently being used as an efficient synthetic route for the synthesis of high molecular weight polymers. ${ }^{22}$ Previously, we reported the synthesis and optical properties of metal-carbon (M-C) $\sigma$-bonded transition metal poly(aryleneethynylene)s. ${ }^{23-26}$ In this study, we describe the synthesis of soluble alkoxy substituted poly(phenyleneethynylene) homo- and hetero-copolymers with biphenylenes in the rigid-rod backbone. The absorption and photoluminescence spectra of the materials are described and compared with the recently reported (please check section 3.3) alkoxy substituted poly(ethynylenephenylene)s. The molecular structures of the previously reported ${ }^{27}$ monomer $\mathrm{Me}_{3} \mathrm{Si}-\mathrm{C} \equiv \mathrm{C}-4$ $\mathrm{C}_{6} \mathrm{H}_{4}-\mathrm{C}_{6} \mathrm{H}_{4}-4-\mathrm{C} \equiv \mathrm{C}-\mathrm{SiMe}_{3}$ and new model compounds M1 and M2 are presented. The effect of their twisted conformations in the absorption and photoluminescence spectra of the monomers and polymers is discussed.

\section{Experimental}

\subsection{Materials and measurements}

Copper(I) iodide, palladium acetate, triphenylphosphine were purchased from Sigma-Aldrich and used as supplied. Ethynylbiphenyl and 4,4-diethynylbiphenyl ${ }^{27}$ and 1,4-bis(butyloxy)-2,5-diiodobenzene, 1,4-bis(octyloxy)-2,5-diiodobenzene, 1,4-diethynyl-2,5-bis (butyloxy) benzene and 1,4-diethynyl-2,5-bis(octyloxy) benzene were prepared by literature procedures. ${ }^{28,29}$ Solvents were pre-dried from appropriate drying agents and freshly distilled before use. ${ }^{30}$

IR spectra were recorded as $\mathrm{CH}_{2} \mathrm{Cl}_{2}$ solutions, in a $\mathrm{NaCl}$ cell, on Nicolet Nexus FTIR spectrometer. All the NMR samples were prepared as $\mathrm{CDCl}_{3}$ solutions, and standard ${ }^{1} \mathrm{H}$ NMR and ${ }^{13} \mathrm{C}\left\{{ }^{1} \mathrm{H}\right\}$ NMR spectra were recorded on Bruker NMR spectrophotometer at 300.22 $\mathrm{MHz}$ and $75.50 \mathrm{MHz}$, respectively. ${ }^{1} \mathrm{H}$ NMR and ${ }^{13} \mathrm{C}$ $\left\{{ }^{1} \mathrm{H}\right\}$ NMR were referenced to solvent resonances. EI Mass spectra were recorded on Autospec Mass spectrometer. Microanalyses were performed at the Department of Chemistry, University of Bath, UK. Molecular weight of the polymer was measured by using a Viscotek VE 7510 GPC instrument. A $30 \mathrm{~cm}$ long PL gel guard column with 10 microns porosity was used using freshly distilled THF. The flow rate was maintained as $1.0 \mathrm{~mL} / \mathrm{min}$. The GPC system was calibrated with polystyrene. Data capture and subsequent data handling was carried out using Viscotek 'Trisec 2000' and 'Trisec 3.0' software.

\subsection{Photoluminescence (PL)}

PL spectra of all the polymers (P1-P5) were taken in dichloromethane solution of concentration $10^{-4}$ $\mathrm{Mol} / \mathrm{dm}^{3}$. The photoluminescence spectra of the solutions were measured using a $10 \mathrm{~mm}$ quartz cell at room temperature using a Perkin Elmer LS55 Luminescence spectrometer. The spectrometer has a range from $200 \mathrm{~nm}$ to $800 \mathrm{~nm}$ for excitation. Optical excitation was provided by a Xenon discharge lamp, spectrally resolved by a Monk-Gillieson type monochromator. The PL spectra of polymers P1 and P2 and of polymers P3-P5 were taken with excitation from the 350 and $420 \mathrm{~nm}$ light beams, respectively. PL spectra of M1 and M2 were taken with excitation from the $320 \mathrm{~nm}$ line at the second absorption band because excitation at the first absorption band results in saturation in PL signal. The excitation lines were chosen such that the absorption was enough to excite the polymers. The PL signals were passed through a second monochromator and the corrected emission data were collected using a red-sensitive (400-900 nm) R928 photomultiplier.

\subsection{Single crystal X-ray crystallography}

Intensity data were collected at $150 \mathrm{~K}$ on a Nonius Kappa CCD equipped with a low temperature device, using graphite monochromated Mo- $K \alpha$ radiation $(\lambda=0.71069 \AA)$ and processed using the Nonius Software. ${ }^{31}$ Empirical absorption corrections were applied using the SORTAV program for the Nonius area detector. For structure solution and refinement, the programs SIR-97 and SHELXL-97, and for illustrations, Ortep-3 were employed, respectively. ${ }^{32-34}$ The structures were refined by full-matrix least squares, on $F^{2}$ and all non-hydrogen atoms were refined with anisotropic displacement parameters; $\mathrm{H}$-atoms were placed in idealized positions and allowed to ride on the relevant carbon atom.

\subsection{Synthesis of the polymers $(\boldsymbol{P 1}, \boldsymbol{P 2}, \boldsymbol{P 5})$}

All the reactions were performed under nitrogen atmosphere, but no special precautions were taken to exclude oxygen during work-up. 
2.4a Poly[1,4-(4,4-biphenylethynyl)-2,5-bis(butyloxy)1,4-phenylene] P1: Polymer precursors 4,4-biphenylethynylene $(0.06 \mathrm{~g}, \quad 0.29 \mathrm{mmol})$ and 1,4-bis (butyloxy)-2,5-diiodobenzene $(0.14 \mathrm{~g}, 0.29 \mathrm{mmol})$ and catalytic amount of $\mathrm{Pd}(\mathrm{OAc})_{2}(2 \mathrm{mg})$, CuI $(2 \mathrm{mg})$ and $\mathrm{PPh}_{3}$ (4 mg) were added to freshly dried diethylamine $(40 \mathrm{~mL})$ in a three-neck flask fitted with a stir bar and reflux condenser under nitrogen atmosphere. The resulting mixture was refluxed for $8 \mathrm{~h}$ during the period of time when a fluorescent greencoloured solution was obtained with the precipitation of amine hydrochloride. The solvent was removed under reduced pressure. The residue was dissolved in minimum volume $(4 \mathrm{~mL})$ of dichloromethane, and then methanol $(60 \mathrm{~mL})$ was added to the solution. A brownish green precipitate was obtained when the solution was allowed to settle at $0^{\circ} \mathrm{C}$. The procedure of re-precipitation from dichloromethane/methanol was repeated three times. The product was obtained as a brownish yellow solid in $68 \%$ yield $(0.08 \mathrm{~g})$. FTIR $\left(\mathrm{CH}_{2} \mathrm{Cl}_{2}, \mathrm{~cm}^{-1}\right): 2105(\mathrm{C} \equiv \mathrm{C}), 3301(\mathrm{C} \equiv \mathrm{CH}) ;{ }^{1} \mathrm{H}$ NMR (300 MHz, $\left.\mathrm{CDCl}_{3}, \delta, \mathrm{ppm}\right): 0.95\left(\mathrm{~m}, \mathrm{CH}_{3}\right), 1.50(\mathrm{~m}$, $\left.\mathrm{CH}_{2}\right), 1.85\left(\mathrm{~m}, \mathrm{CH}_{2}\right), 3.08(\mathrm{~s}, \mathrm{C} \equiv \mathrm{CH}), 4.00\left(\mathrm{~m}, \mathrm{OCH}_{2}\right)$, 6.86 (s, terminal Ar), 6.98 (s, Ar), 7.25 (s, terminal Ar), $7.54\left(\mathrm{~m}, \mathrm{C}_{6} \mathrm{H}_{4} \mathrm{C}_{6} \mathrm{H}_{4}\right) ;{ }^{13} \mathrm{C} \mathrm{NMR}\left(76 \mathrm{MHz}, \mathrm{CDCl}_{3}, \delta\right.$, ppm): $14.33,19.75,31.80$ and $69.78\left(\right.$ all- $\left.\mathrm{CH}_{2} \mathrm{CH}_{3}\right)$, $117.36,127.25,127.32,132.47,133.04,133.44$, 140.41 and 154.11 (Ar). $M_{w}=8310, M_{n}=2100$, $M_{w} / M_{n}=4$.

2.4b Poly[1,4-(4,4-biphenylethynyl)-2,5-bis(octyloxy)1,4-phenylene] P2: By the application of the procedure of P1, utilizing 4,4-biphenylethynylene $(0.07 \mathrm{~g}$, $0.35 \mathrm{mmol}$ ) and 1,4-bis(octyloxy)-2,5-diiodobenzene $(0.20 \mathrm{~g}, 0.35 \mathrm{mmol})$ afforded $\mathbf{P 2}$ as yellow solid in $71 \%$ yield $(0.13 \mathrm{~g})$. FTIR $\left(\mathrm{CH}_{2} \mathrm{Cl}_{2}, \mathrm{~cm}^{-1}\right): 2202(\mathrm{C} \equiv \mathrm{C})$; ${ }^{1} \mathrm{H}$ NMR (300 MHz, $\left.\mathrm{CDCl}_{3}, \delta, \mathrm{ppm}\right): 0.80\left(\mathrm{~m}, \mathrm{CH}_{3}\right)$, $1.25\left(\mathrm{~m}, \mathrm{CH}_{2}\right), 1.50\left(\mathrm{~m}, \mathrm{CH}_{2}\right), 1.80\left(\mathrm{~m}, \mathrm{CH}_{2}\right), 3.95(\mathrm{~m}$, $\left.\mathrm{OCH}_{2}\right), 6.86(\mathrm{~s}$, terminal Ar), $6.97(\mathrm{~s}, \mathrm{Ar}-\mathrm{H}), 7.24(\mathrm{~s}$, terminal $\mathrm{Ar}), 7.55\left(\mathrm{~m}, \mathrm{C}_{6} \mathrm{H}_{4} \mathrm{C}_{6} \mathrm{H}_{4}\right) ;{ }^{13} \mathrm{C} \mathrm{NMR}(76 \mathrm{MHz}$, $\left.\mathrm{CDCl}_{3}, \delta, \mathrm{ppm}\right): 14.50,23.09,26.52,29.55,29.74$, 29.78, 29.82, 32.24 and $70.08\left(\right.$ all- $\left.\mathrm{CH}_{2} \mathrm{CH}_{3}\right), 114.45$, $127.23,127.36,132.49,133.45,140.43,152.29$, 154.11 and $154.79(\mathrm{Ar}) . M_{w}=13,200, M_{n}=5,600$, $M_{w} / M_{n}=2.5$.

2.4c Poly[1,4-bis(ethynyl)-2-5-bis(octyloxy)phenylene2,5-bis(butoxy)-1,4-phenylene)] P5: By applying the same synthetic procedure as described for P1, using 1,4-bis(ethynyl)-2-5-bis(octyloxy)phenylene (0.05 g, $0.13 \mathrm{mmol}$ ) and 1,4-bis(butyloxy)-2,5-diiodobenzene (0.06 g, $0.13 \mathrm{mmol}), \quad$ P5 was obtained as a brownish-yellow solid in $83 \%$ yield (0.06 g). FTIR $\left(\mathrm{CH}_{2} \mathrm{Cl}_{2}, \mathrm{~cm}^{-1}\right)$ : $2202(\mathrm{C} \equiv \mathrm{C}) ;{ }^{1} \mathrm{H}$ NMR $(300 \mathrm{MHz}$, $\left.\mathrm{CDCl}_{3}, \delta, \mathrm{ppm}\right): 0.80\left(\mathrm{~m}, \mathrm{CH}_{3}\right), 0.91\left(\mathrm{t}, \mathrm{CH}_{3}\right), 1.25$ $\left(\mathrm{m}, \mathrm{CH}_{2}\right), 1.52\left(\mathrm{~m}, \mathrm{CH}_{2}\right), 1.80\left(\mathrm{~m}, \mathrm{CH}_{2}\right), 3.90$ (bs, $\mathrm{OCH}_{2}$ ), 6.85 (bs, Ar), 6.95 (s, Ar), 7.24 (s, Ar). $M_{w}=$ 9,340, $M_{n}=4,460, M_{w} / M_{n}=2.1$.

\subsection{Synthesis of model compounds $(\mathbf{M 1}, \mathbf{M 2})$}

2.5a 1,4-Bis(4,4-biphenylethynyl)-2,5-bis(butyloxy)benzene M1: To a solution of 1,4-bis(butyloxy)-2,5diiodobenzene $(0.30 \mathrm{~g}, 0.68 \mathrm{mmol})$ in $\mathrm{Et}_{2} \mathrm{NH}(30 \mathrm{~mL})$ were added 4,4-biphenylethynyl (0.30 g, $1.69 \mathrm{mmol})$, copper(I) iodide $(7 \mathrm{mg})$, palladium acetate $(7 \mathrm{mg})$ and triphenylphosphine $(20 \mathrm{mg})$, and the resulting mixture was refluxed for $8 \mathrm{~h}$ under nitrogen atmosphere. After the completion of the reaction, the solvent was removed under reduced pressure. The crude product was dissolved in minimum volume (3-4 mL) of dichloromethane, and then $50-60 \mathrm{~mL}$ methanol was added to the solution. The product was precipitated out which was collected in a sintered crucible in $90 \%$ yield $(0.35 \mathrm{~g})$. The crystals of the compound were obtained from the recrystallization of the pure product from a dichloromethane/hexane solvent system. ${ }^{1} \mathrm{H}$ NMR (300 $\mathrm{MHz}, \mathrm{CDCl}_{3}, \delta, \mathrm{ppm}$ ): 0.95 (t, 6H, $\left.\mathrm{CH}_{3}\right), 1.53$ (m, 4H, $\left.\mathrm{CH}_{2}\right), 1.58\left(\mathrm{~m}, 4 \mathrm{H}, \mathrm{CH}_{2}\right), 4.10\left(\mathrm{t}, 4 \mathrm{H}, \mathrm{OCH}_{2}\right), 6.95$ (s, 2H, Ar), 7.29 (t, 2H, Ar), 7.38 (t, 4H, Ar), 7.53 (br-m, 12H, Ar); ${ }^{13} \mathrm{C}$ NMR (76 MHz, $\mathrm{CDCl}_{3}, \delta, \mathrm{ppm}$ ): $14.35,19.70,31.80$ and $69.75\left(\mathrm{OCH}_{2} \mathrm{CH}_{2} \mathrm{CH}_{2} \mathrm{CH}_{3}\right)$, 87.11 and $95.23(\mathrm{C} \equiv \mathrm{C}), 114.41,117.32,122.78$, $127.42,128.04,129.27,132.39,140.76,141.33$ and 154.07 (Ar). MS (EI): $m / z, 574.3$; Anal. Calc. for $\mathrm{C}_{42} \mathrm{H}_{38} \mathrm{O}_{2}$ : C, 87.77, H, 6.66; Found: C, 87.60, H, $6.57 \%$.

2.5b 1, 4-Bis(4, 4-biphenylethynyl)-2,5-bis(octyloxy)benzene M2: Using the procedures described for M1, 1,4-bis(octyloxy)-2,5-diiodobenzene $\quad(0.25 \mathrm{~g}, \quad 0.45$ mmol ) and 4,4-biphenylethynyl (0.20 g, $1.13 \mathrm{mmol})$ yielded pale-brown $\mathbf{M} 2$ in $87 \%(0.27 \mathrm{~g}) .{ }^{1} \mathrm{H}$ NMR (300 MHz, $\mathrm{CDCl}_{3}, \delta, \mathrm{ppm}$ ): $0.8\left(\mathrm{t}, 6 \mathrm{H}, \mathrm{CH}_{3}\right), 1.22$ (m, $\left.12 \mathrm{H}, \mathrm{CH}_{2} \mathrm{CH}_{2} \mathrm{CH}_{2}\right), 1.45\left(\mathrm{~m}, 8 \mathrm{H}, \mathrm{CH}_{2} \mathrm{CH}_{2}\right), 1.85$ (m, 4H, $\left.\mathrm{CH}_{2}\right), 1.40\left(\mathrm{~m}, 4 \mathrm{H}, \mathrm{OCH}_{2}\right), 6.95$ (s, 2H, Ar), 7.30 (t, 2H, Ar), 7.38 (t, 4H, Ar), 7.54 (br-m, 12H, $\mathrm{Ar}) ;{ }^{13} \mathrm{C} \mathrm{NMR}\left(76 \mathrm{MHz}, \mathrm{CDCl}_{3}, \delta, \mathrm{ppm}\right): 14.53$, 23.11, 26.52, 29.75, 29.80, 29.83, 32.25 and 70.06 (all$\left.\mathrm{CH}_{2}\right), 87.12,95.24(\mathrm{C} \equiv \mathrm{C}), 114.40,117.31,122.78$, 127.40, 129.27, 132.41, 133.36, 140.77, 141.34, and 154.07 (Ar); MS (EI): $m / z, 686.6$; Anal. Calc. for $\mathrm{C}_{42} \mathrm{H}_{38} \mathrm{O}_{2}$ : C, 87.42, H, 7.92; Found: C, 87.30, H, $7.68 \%$. 


\section{Results and Discussion}

\subsection{Synthesis and characterization of polymers and model compounds}

The new alkoxy ethynyl polymers and their molecular precursors were prepared using a Sonogashira crosscoupling reaction ${ }^{21}$ as illustrated in scheme 1. Equimolar quantity of 1,4-bis(butyloxy)-2,5-diiodobenzene and 4,4-diethynylbiphenyl were reacted in the presence of catalytic amounts of $\mathrm{Pd}(\mathrm{OAc})_{2}, \mathrm{CuI}$ and $\mathrm{PPh}_{3}$, in diethylamine, at $55^{\circ} \mathrm{C}$, for $8 \mathrm{~h}$ to afford expected copolymer P1. The polymer was isolated as brownishyellow solid in $68 \%$ yield after repeated precipitation from $\mathrm{CH}_{2} \mathrm{Cl}_{2}$ by methanol. Polymers P2, P3, P4 and P5 were prepared similarly using equimolar quantities of aryl diiodides and diethynyl aryl compounds. The homo-polymer P3 and P4 have been reported previously using a different route involving reactions of tributyl tin reagents which gives higher molecular weight. ${ }^{35}$ The co-polymer P5 represents a new class of co-polymer in which alternate arene rings in the polymer chain have different alkoxy substituents. The model compounds M1 and M2 were formed similarly, but using 2.5 equivalents of mono-terminal ethynylbiphenyl instead of di-terminal 4, 4-diethynylbiphenyl.

The polymers and model molecular compounds are moderately soluble in dichloromethane, chloroform and THF. The solubility of octyloxy substituted polymers is much higher than the corresponding butyloxy substituted polymers. All the polymers are air stable. The molecular weights were determined by gel permeation chromatography (GPC), and the number average molecular weights of P1, P2, P3, P4 and P5 are 2100, 5260, 3130, 4840 and 9340, respectively. The molecular weights of the polymers, especially for P1 and P3 appeared to be very low, but they have substantial differences between their molecular weight distributions. The weight average molecular weights $\left(M_{w}\right)$, number average molecular weights $\left(M_{n}\right)$ and molecular weight distribution values of the polymers are shown in table 1.

The molecular compounds were characterized initially by ${ }^{1} \mathrm{H}$ NMR and ${ }^{13} \mathrm{C}$ NMR spectroscopy. In M1, the aliphatic protons of the methyl and methylene groups bonded to oxygen displayed triplets at $\delta=0.95$ and 4.10 ppm, respectively; and the other $\mathrm{CH}_{2}$ groups appeared as multiplets at $\delta=1.50,1.75$ and $1.85 \mathrm{ppm}$. The aromatic protons of the arene rings bonded to the alkoxy groups were detected at $\delta 6.95 \mathrm{ppm}$ as a singlet. In the ${ }^{13} \mathrm{C}$ NMR spectrum of M1, the carbon belonging to butoxy side chain gave signals at $\delta=14.35,19.70$, 31.80 and $69.75 \mathrm{ppm}$, and the carbons belonging to ethynyl groups were observed at $\delta=87.11$ and 95.23 ppm, and the signals at $\delta=114.41,117.32,122.78$, $127.42,128.04,129.27,132.39,140.76,141.33$ and $154.07 \mathrm{ppm}$ were assigned to aromatic carbons. Compound M2 displayed similar spectral pattern in its ${ }^{1} \mathrm{H}$ and ${ }^{13} \mathrm{C}$ NMR spectra.

For P1, the presence of ethynyl fragments in the polymer backbone was confirmed by the IR stretching frequency at $2105 \mathrm{~cm}^{-1}$. In addition, an IR stretching frequency at $3301 \mathrm{~cm}^{-1}$ showed the presence of terminal acetylene group suggesting the lower molecular weight of the polymer. For polymer $\mathbf{P} 2, v(\mathrm{C} \equiv \mathrm{C})$ was observed at $2202 \mathrm{~cm}^{-1}$, but no peak for terminal acetylenic hydrogen was seen in the $3300 \mathrm{~cm}^{-1}$ region
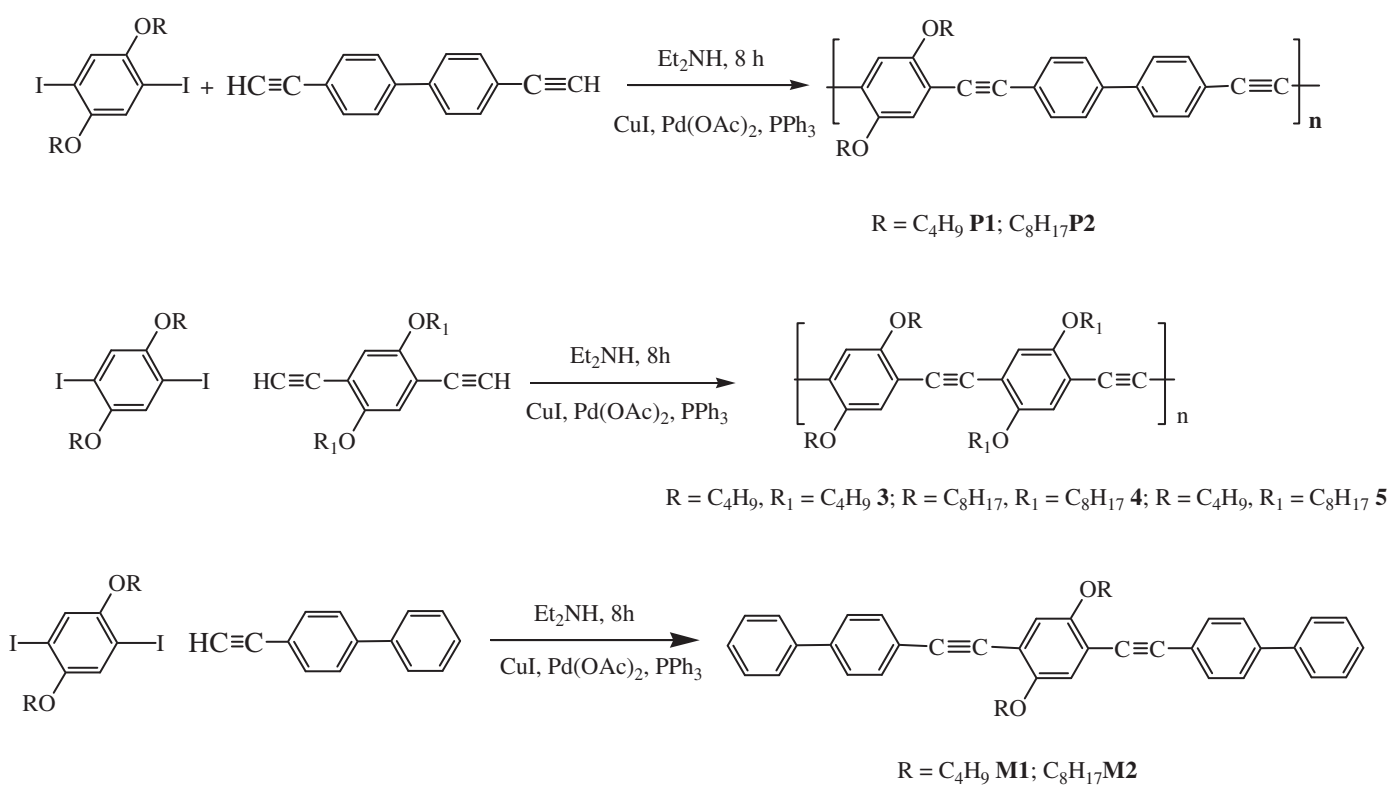

Scheme 1. Synthesis of poly(2,5-dialkoxy-1,4-phenylene-4,4-biphenyleneethynylene)s and their model compounds. 
Table 1. Molecular weights and absorption and photoluminescence spectral data of the polymers (P1-P5) and the model compounds (M1, M2)

\begin{tabular}{lccccccc}
\hline Compounds & ${ }^{\mathrm{a}} \mathrm{M} . \mathrm{p} .\left({ }^{\circ} \mathrm{C}\right)$ & ${ }^{\mathrm{b}} \mathrm{M}_{\mathrm{w}}$ & ${ }^{\mathrm{c}} \mathrm{M}_{\mathrm{n}}$ & $\mathrm{M}_{\mathrm{w}} / \mathrm{M}_{\mathrm{n}}$ & ${ }^{\mathrm{d}} \lambda(\mathrm{nm})$ & ${ }^{\mathrm{e}} \lambda(\mathrm{nm})$ & ${ }^{\mathrm{f}} \log \varepsilon$ \\
\hline P1 & $181^{*}$ & 8310 & 2100 & 4 & 385 & 466 & 4.48 \\
P2 & 190 & 13200 & 5260 & 2.5 & 390 & 463 & 5.25 \\
P3 & $170^{*}$ & 8770 & 3130 & 2.8 & 433 & 514 & 4.63 \\
P4 & 161 & 10400 & 4840 & 2.2 & 436 & 490,511 & 4.60 \\
P5 & 140 & 9340 & 4460 & 2.1 & 437 & 510 & 4.77 \\
M1 & - & - & - & - & 378 & 433 & 0.97 \\
M2 & - & - & - & - & 370 & 437 & 0.11 \\
\hline
\end{tabular}

${ }^{\mathrm{a}}$ Melting point, *Decomposition point, ${ }^{\mathrm{b}}$ Weight average molecular weight, ${ }^{\mathrm{c}}$ Number average molecular weight, ${ }^{\mathrm{d}}$ Absorption maximum wavelength, ${ }^{\mathrm{e}}$ Emission maximum wavelength, ${ }^{\mathrm{f}}$ Logarithm of absorption co-efficient $\left(\mathrm{M}^{-1} \mathrm{~cm}^{-1}\right)$.

demonstrating the formation higher molecular weight polymer as evident by the GPC. Similarly, for P3, P4 and P5, $v(\mathrm{C} \equiv \mathrm{C})$ were observed at 2197, 2202 and 2202 $\mathrm{cm}^{-1}$, respectively. As expected, for lower molecular weight polymer P3, $v$ ( $\equiv \mathrm{C}-\mathrm{H})$ was observed at 3301 $\mathrm{cm}^{-1}$ indicating the ethynyl group as terminal end group of the polymer.

The characterization of the polymers was also possible from analysis of the ${ }^{1} \mathrm{H}$ NMR spectra, however, the ${ }^{13} \mathrm{C}$ NMR spectra of the polymers failed to show all the signals for the carbon skeleton especially in the aromatic region. This can be attributed to the lower solubility of the polymers. For polymer P1, the butoxy protons - $\mathrm{CH}_{3},-\mathrm{CH}_{2},-\mathrm{CH}_{2}$ and $\mathrm{O}-\mathrm{CH}_{2}$ displayed signals as multiplets and broad triplet at $\delta=0.95,1.50,1.85,4.00$ $\mathrm{ppm}$, respectively. The terminal ethynyl protons were detected at $\delta=3.1 \mathrm{ppm}$ indicating the presence of terminal acetylene as end groups in the polymer. In the aromatic region of polymer $\mathbf{P 1}$, three singlets $\delta=6.86$, 6.98 and $7.25 \mathrm{ppm}$ were observed. Among them, signals at 6.86 and $7.25 \mathrm{ppm}$ were characterized for the two protons of the terminal iodine substituted butyloxy aryl fragments, and signal at $6.98 \mathrm{ppm}$ was characterized for the protons of butyloxy aryl fragments in the polymer core. Polymer P2 and P5 also give ${ }^{1} \mathrm{H}$ NMR signals in the expected aliphatic and aromatic region. The nature of the known polymers $\mathbf{P 3}$ and $\mathbf{P 4}$ was confirmed by comparison of the spectroscopic data with the previously published results. ${ }^{35}$

\subsection{Crystal structure determinations of model compounds}

The crystal structures of M1 (CCDC-997486), M2 (CCDC-997487) and $\mathrm{Me}_{3} \mathrm{Si}-\mathrm{C} \equiv \mathrm{C}-4-\mathrm{C}_{6} \mathrm{H}_{4}-\mathrm{C}_{6} \mathrm{H}_{4}-4-$ $\mathrm{C} \equiv \mathrm{C}-\mathrm{SiMe}_{3}$ (CCDC-997488) have been determined using single crystal $\mathrm{X}$-ray diffraction techniques in order to study the ring conformations along the molecular chains in the model compounds, so that these can be related to the conformations in the polymers. Potentially, the most significant structural feature is the twist, or dihedral angle between the two adjacent arene rings in the biphenyl units, as this may influence the extent of the $\pi$ overlap along the chains. There is essentially free rotation about the alkynyl $\mathrm{C} \equiv \mathrm{C}$ triple bonds so that the orientation of the biphenyl units with respect to the central alkoxy-substituted arene ring should have less significance.

The molecular structure of M1 is shown in figure 1, and confirms the spectroscopic assignments, with the $\mathrm{OC}_{4} \mathrm{H}_{9}$ chains at the 2 and 5 positions. The bond parameters within the molecule do not deviate significantly from expected values, and the alkynyl units are essentially linear $\left\{\mathrm{C}(13)-\mathrm{C}(15)-\mathrm{C}(16), 179.7(3)^{\circ}\right.$; $\mathrm{C}(15)-\mathrm{C}(16)-\mathrm{C}(17), \quad 177.3(2)^{\circ} ; \quad \mathrm{C}(10)-\mathrm{C}(29)-\mathrm{C}(30)$, $\left.179.0(2)^{\circ}, \mathrm{C}(29)-\mathrm{C}(30)-\mathrm{C}(31), 178.0(2)^{\circ}\right\}$. Of interest is the dihedral angle of only $2.3^{\circ}$ between the arene rings $\mathrm{C}(17) \mathrm{C}(18) \mathrm{C}(19) \mathrm{C}(20) \mathrm{C}(27) \mathrm{C}(28)$ and $\mathrm{C}(21) \mathrm{C}(22) \mathrm{C}(23) \mathrm{C}(24) \mathrm{C}(25) \mathrm{C}(26)$ and of only $1.1^{\circ}$ between rings $\mathrm{C}(31) \mathrm{C}(32) \mathrm{C}(33) \mathrm{C}(34) \mathrm{C}(41) \mathrm{C}(42)$ and $\mathrm{C}(35) \mathrm{C}(36) \mathrm{C}(37) \mathrm{C}(38) \mathrm{C}(39) \mathrm{C}(40)$. The inner arene rings of the two biphenyl groups make angles of $29.0^{\circ}\{\mathrm{C}(17) \mathrm{C}(18) \mathrm{C}(19) \mathrm{C}(20) \mathrm{C}(27) \mathrm{C}(28)\}$ and $29.3^{\circ}$ $\{\mathrm{C}(31) \mathrm{C}(32) \mathrm{C}(33) \mathrm{C}(34) \mathrm{C}(41) \mathrm{C}(42)\}$ with the alkoxysubstituted central arene ring $\{\mathrm{C}(9) \mathrm{C}(10) \mathrm{C}(11) \mathrm{C}(12)$ $\mathrm{C}(13) \mathrm{C}(14)]$, respectively. An examination of the crystal packing shows no evidence of $\pi-\pi$ stacking and there are no hydrogen bond interactions present.

Similarly, an examination of the crystal packing in the structure of $\mathbf{M} 2$ provides no evidence of hydrogen bonding interactions or $\pi-\pi$ stacking. However, there is greater evidence of inter-digitation between the longer $\mathrm{OC}_{8} \mathrm{H}_{17}$ chains between adjacent molecules. The molecular structure of $\mathbf{M} 2$ is illustrated in figure 2 . The molecule sits on a crystallographic centre 


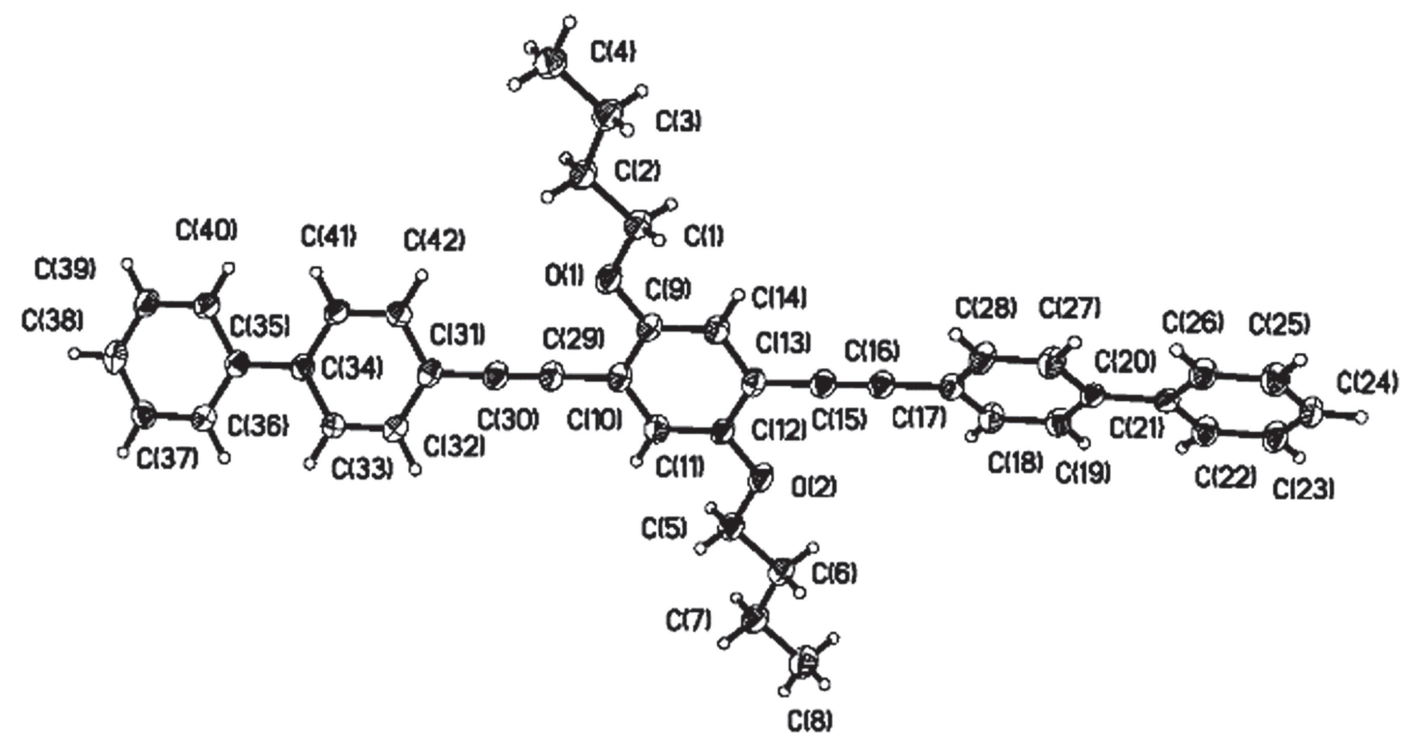

Figure 1. The molecular structure of $\mathrm{C}_{6} \mathrm{H}_{5}-4-\mathrm{C}_{6} \mathrm{H}_{4}-\mathrm{C} \equiv \mathrm{C}-\mathrm{C}_{6} \mathrm{H}_{4}\left(2,5-\mathrm{OC}_{4} \mathrm{H}_{9}\right)_{2}-\mathrm{C}_{6} \mathrm{H}_{4}-4-\mathrm{C}_{6} \mathrm{H}_{5}$ M1 showing the atom numbering scheme adopted. The atomic displacement ellipsoids are drawn at the $50 \%$ level.

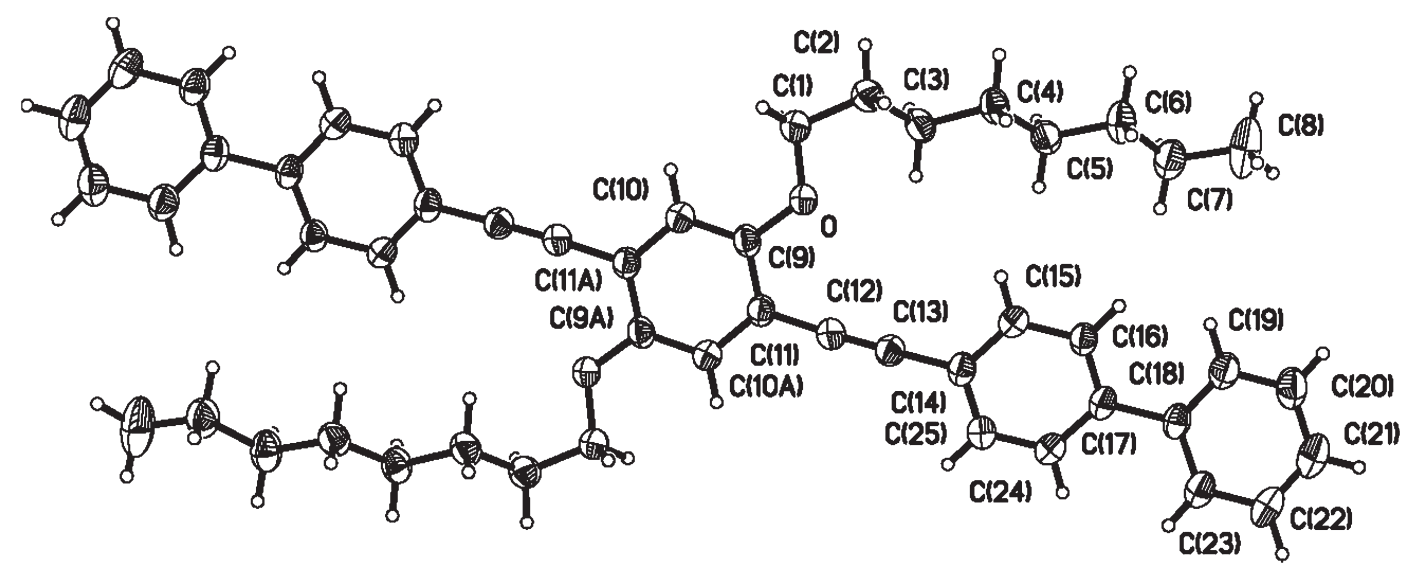

Figure 2. The molecular structure of $\mathrm{C}_{6} \mathrm{H}_{5}-4-\mathrm{C}_{6} \mathrm{H}_{4}-\mathrm{C} \equiv \mathrm{C}-\mathrm{C}_{6} \mathrm{H}_{4}\left(2,5-\mathrm{OC}_{8} \mathrm{H}_{17}\right)_{2}-\mathrm{C}_{6} \mathrm{H}_{4}-4-\mathrm{C}_{6} \mathrm{H}_{5} \mathbf{M 2}$ showing the atom numbering scheme adopted. The atomic displacement ellipsoids are drawn at the $50 \%$ level.

of symmetry positioned at the centroid of the central arene ring and, therefore, the asymmetric unit contains half a molecule. As for M1, the bond parameters in the structure of $\mathbf{M} 2$ are unremarkable, and the alkynyl groups are essentially linear $\{\mathrm{C}(11)-\mathrm{C}(12)$ $\left.\mathrm{C}(13), \quad 177.1(3)^{\circ} ; \quad \mathrm{C}(12)-\mathrm{C}(13)-\mathrm{C}(14), \quad 178.9(3)^{\circ}\right\}$. However, in contrast to M1, in M2 the dihedral angle between the rings of the independent biphenyl group is $29.2^{\circ}$, and the angle between the inner biphenyl ring $\{\mathrm{C}(14) \mathrm{C}(15) \mathrm{C}(16) \mathrm{C}(17) \mathrm{C}(24) \mathrm{C}(25)\}$ and the central alkoxy-substituted arene ring $\{\mathrm{C}(9) \mathrm{C}(10) \mathrm{C}(11) \mathrm{C}(9 \mathrm{~A}) \mathrm{C}(10 \mathrm{~A}) \mathrm{C}(11 \mathrm{~A})\}$ is $9.4^{\circ}$. Thus, the relative orientations of the ring systems in $\mathbf{M 1}$ and M2 are significantly different in the solid state.
The dihedral angles in $\mathbf{M} 1$ and $\mathbf{M} 2$ may be compared with those observed in $\mathrm{Me}_{3} \mathrm{Si}-\mathrm{C} \equiv \mathrm{C}-4-\mathrm{C}_{6} \mathrm{H}_{4}-$ $\mathrm{C}_{6} \mathrm{H}_{4}-4-\mathrm{C} \equiv \mathrm{C}-\mathrm{SiMe}_{3}$, the structure of which was determined as part of the overall project, and with other molecules, whose structures have been reported in the literature, that contain the $\mathrm{C} \equiv \mathrm{C}-4-\mathrm{C}_{6} \mathrm{H}_{4}-\mathrm{C}_{6} \mathrm{H}_{4}$ 4- $\mathrm{C} \equiv \mathrm{C}$ unit. ${ }^{36,37}$ Molecules of $\mathrm{Me}_{3} \mathrm{Si}-\mathrm{C} \equiv \mathrm{C}-4-\mathrm{C}_{6} \mathrm{H}_{4}$ $\mathrm{C}_{6} \mathrm{H}_{4}-4-\mathrm{C} \equiv \mathrm{C}-\mathrm{SiMe}_{3}$ crystallize in the triclinic space group $P-1$ (no. 2) with two independent, but structurally similar, molecules in the asymmetric unit. There are no significant intermolecular interactions present in the crystal lattice. The molecular structure of one of two independent molecules is shown in figure 3, and the dihedral angle between the 


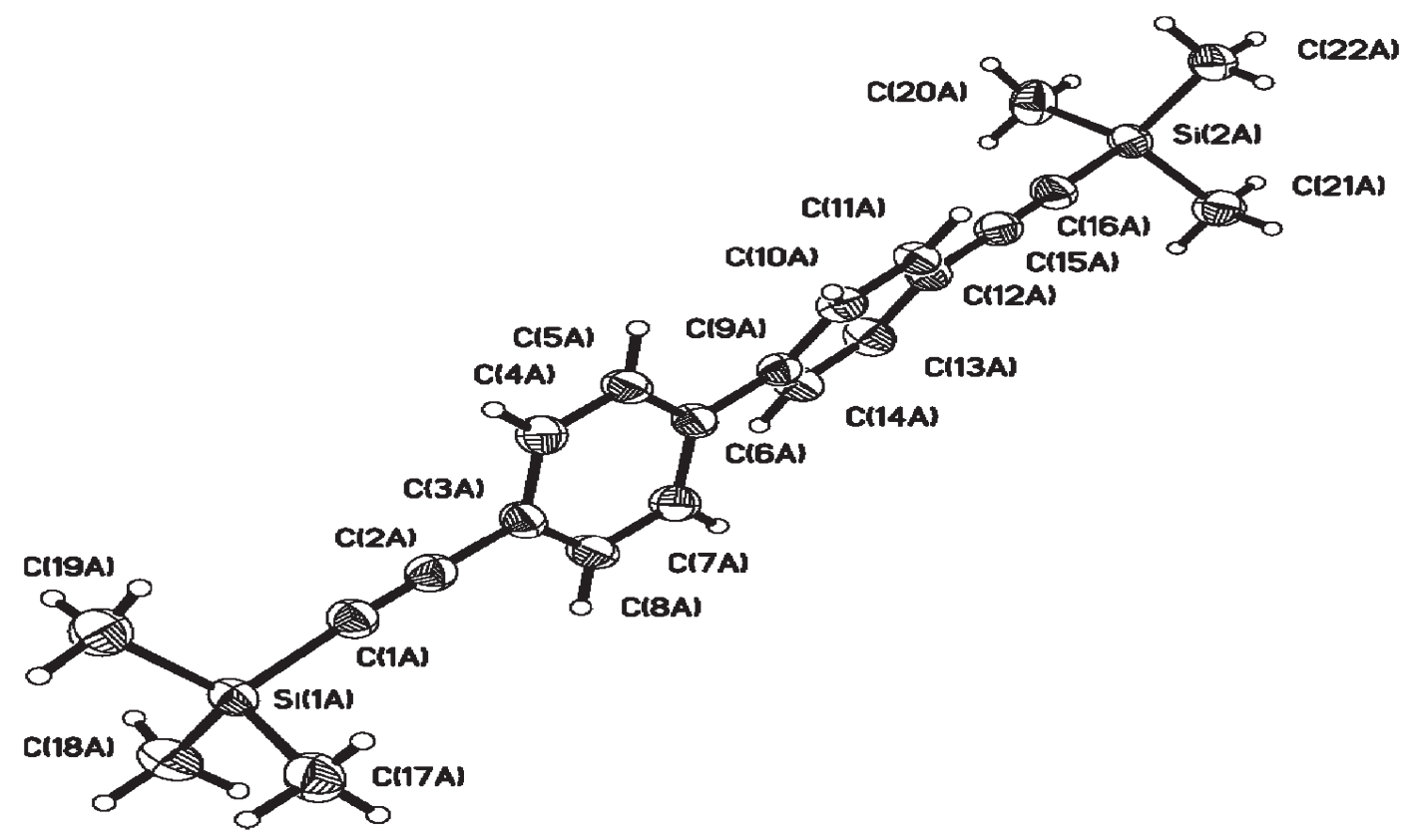

Figure 3. The molecular structure of one of the two independent molecules of $\mathrm{Me}_{3} \mathrm{Si}-\mathrm{C} \equiv \mathrm{C}-4$ $\mathrm{C}_{6} \mathrm{H}_{4}-\mathrm{C}_{6} \mathrm{H}_{4}-4-\mathrm{C} \equiv \mathrm{C}-\mathrm{SiMe}_{3}$ showing the atom numbering scheme adopted. The atomic displacement ellipsoids are drawn at the $50 \%$ level.

arene rings $\{\mathrm{C}(3 \mathrm{~A}) \mathrm{C}(4 \mathrm{~A}) \mathrm{C}(5 \mathrm{~A}) \mathrm{C}(6 \mathrm{~A}) \mathrm{C}(7 \mathrm{~A}) \mathrm{C}(8 \mathrm{~A})\}$ and $\{\mathrm{C}(9 \mathrm{~A}) \mathrm{C}(10 \mathrm{~A}) \mathrm{C}(11 \mathrm{~A}) \mathrm{C}(12 \mathrm{~A}) \mathrm{C}(13 \mathrm{~A}) \mathrm{C}(14 \mathrm{~A})$ is $32.1^{\circ}\left(32.9^{\circ}\right.$ in the second molecule). This compares well with the value of $29.2^{\circ}$ observed in M2. Of the other structures in the Cambridge Structural Database ${ }^{38}$ that contain the $\mathrm{C} \equiv \mathrm{C}-4-\mathrm{C}_{6} \mathrm{H}_{4}-\mathrm{C}_{6} \mathrm{H}_{4}-4-\mathrm{C} \equiv \mathrm{C}$ the dihedral angles between the two arene ring range from $0.0^{\circ}$ (constrained by crystal symmetry) to $29.6^{\circ} .36,37$ Therefore, the values for the dihedral angle found in the solid state structures of M1 and M2 are in the expected range, although M1, with dihedral angles of 1.1 and $2.3^{\circ}$, displays the smallest dihedral angle in any reported system where crystallographic symmetry is not imposed on the orientation. The deviation from planarity is related to the reduction of the steric interactions between the ring hydrogen atoms on the adjacent ring systems, and these distortions (maximum $\mathrm{ca} .30^{\circ}$ ) have a significant influence on the delocalization along the molecular chains.

\subsection{Optical spectroscopy (absorption and photoluminescence) of the polymers and model monomers}

Figure $4 \mathrm{a}-\mathrm{d}$ shows the absorption and photoluminescence spectra of the model compounds M1 and M2, and polymers P1-P5 measured in dichloromethane solution, at room temperature. In contrast to the unsubstituted 1,4-bis(phenyleneethynylene)benzene where one broad absorption band was observed in the spectral region $250-350 \mathrm{~nm},{ }^{39}$ the alkoxy substituted model compounds M1 and M2 displayed two peaks of almost equal intensity centered at 320 and $360 \mathrm{~nm}$ (figure 4a). Alkoxy substitutents in M1 and M2 modify the central arene ring $\pi$-orbitals through resonance interaction with oxygen lone pairs. This leads to the developments of two HOMO orbitals, HOMO-1 and HOMO-2, and electronic transition from these orbitals to the LUMO resulted two separate bands. ${ }^{40}$ These principal bands are associated with the rigid-rod backbone of the molecules. ${ }^{35}$ Similar spectral features were reported by Li et al. for alkoxy substituted PPEs. ${ }^{12}$

All the relevant spectral parameters are summarized in table 1. Two separate spectral patterns were observed in the absorption spectra for the two different sets of polymers (figure 4b). The first set, P1 and P2, contain biphenylene fragments that alternate with the ethynyl alkoxy phenylene units in the polymer. In contrast, the second set P3, P4 and P5 are homopolymers that have only ethynyl alkoxy phenylenes as repeating unit. The spectra of P3, P4 and P5 consist of three bands in the measured spectral range. The first absorption band is centred at $437 \mathrm{~nm}$, the second band is centred at $310 \mathrm{~nm}$ and a third is a shoulder centred at $225 \mathrm{~nm}$. The lowest energy band of the co-polymers P1 and P2 was observed at $387 \mathrm{~nm}$ which is blue shifted by $50 \mathrm{~nm}$ with respect to the homopolymer P3, P4 and P5 (figure 4b). The shift of absorption bands from monophenyl to biphenyl in the polymer backbone can be explained by analyzing the molecular structure of 


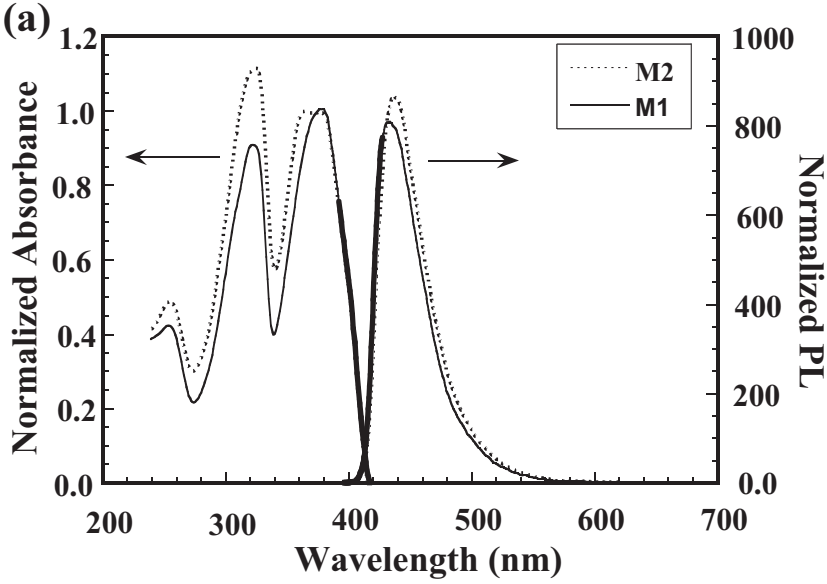

(b)

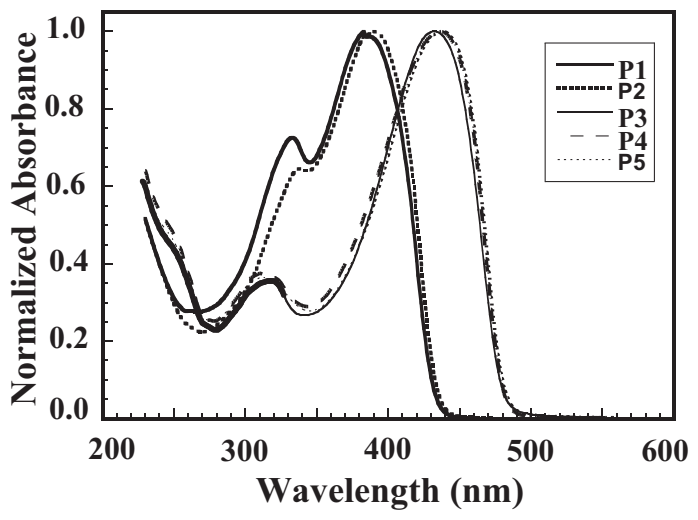

(c)

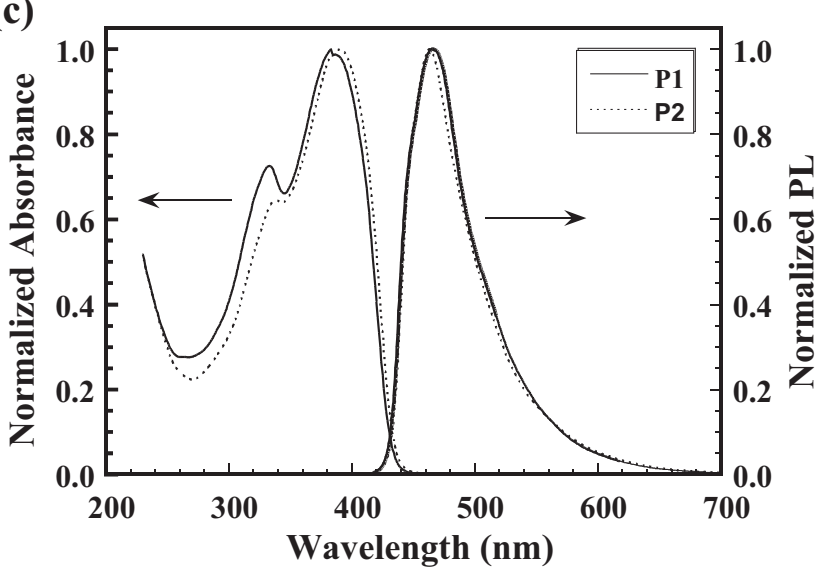

(d)

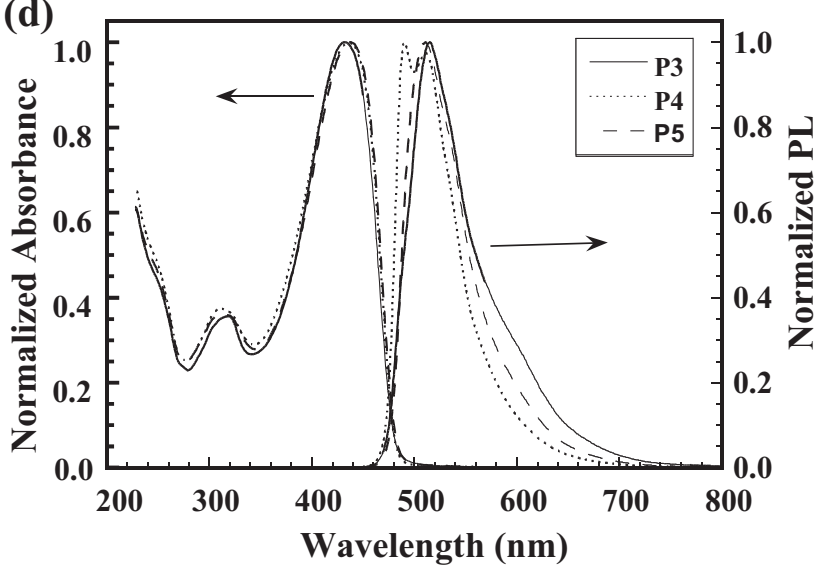

Figure 4. (a) The solution absorption and photoluminescence spectra of the model compounds M1 and M2; (b) The solution absorption spectra for the polymers P1 - P5; (c) The absorption and photoluminescence spectra of the polymers P1 and P2 recorded at room temperature; (d) The absorption and photoluminescence spectra of the polymers P3 - P5 recorded at room temperature.

the building block $\mathrm{Me}_{3} \mathrm{Si}-\mathrm{C} \equiv \mathrm{C}-4-\mathrm{C}_{6} \mathrm{H}_{4}-\mathrm{C}_{6} \mathrm{H}_{4}-4-\mathrm{C} \equiv \mathrm{C}-$ $\mathrm{SiMe}_{3}$. The dihedral angle (torsion angle) between the two phenyl rings is $32.1^{\circ}$. This deviation of the planarity in the phenyl rings of the polymers reduced conjugation among the polymer backbone causing the blue shift in the lowest absorption bands. ${ }^{40}$ Similar blue shift of the lowest absorption bands were observed in case of the alkoxy substituted co-polymers where every second benzene rings are unsubstituted in the polymers. ${ }^{12}$ No significant effect of the chain length of the alkoxy group was observed in the UV spectra of the polymers described here or in related systems. ${ }^{41}$

Photoluminescence (PL) measurements were carried out on the materials in order to establish their luminescent properties to assess their potential into electrooptic devices. Figure 4a shows the absorption and PL of M1 and M2. Both materials show an emission band centred at around $435 \mathrm{~nm}$. Figure $4 \mathrm{c}$ and $4 \mathrm{~d}$ show the room temperature photoluminescence spectra of the polymers. The photoluminescence (PL) spectra of all the polymers display one emission band peaking at $475-510 \mathrm{~nm}$ range. The small energy shift (Stokes shift) between absorption and emission bands confirmed that the origin of emission is singlet excited state. Recent study on the alkoxy molecular system suggests that the excited state geometry of the phenylethynyls is more planar compared to the ground state indicating the presence of single emitting species. ${ }^{40}$ Similar emission spectra have been observed by other groups. ${ }^{35}$ No emission from triplet excited state was observed. However, it is expected that the triplet state will be at a constant separation of $0.7 \pm 0.1 \mathrm{eV}$ below the first singlet state. ${ }^{42}$ The evolution of the first triplet excited state in an extensive series of platinum containing phenyleneethynylene monomers and polymers and in an analogous series of all-organic polymers where the platinum fragments is replaced by a phenylene group has been studied. ${ }^{42}$ Introduction of a heavy metal such as platinum in the main chain of these polymers can induce spin-orbit coupling, and emission from the 
triplet state (phosphorescence) can be easily detected, but only at low temperatures in the solid state. ${ }^{43}$

\section{Conclusions}

Using a palladium/copper catalyzed coupling reaction a new series of co-polymers poly(2,5-dialkoxy-4phenyleneethynylene-4,4-biphenyleneethynylene)s of the general formula $\left[-\mathrm{C} \equiv \mathrm{C}-4-\mathrm{C}_{6} \mathrm{H}_{4}-\mathrm{C}_{6} \mathrm{H}_{4}-4-\mathrm{C} \equiv \mathrm{C}\right.$ $\left.\mathrm{C}_{6} \mathrm{H}_{4}(2,5-\mathrm{OR})_{2}-\right]_{\mathrm{n}}\left(\mathrm{R}=\mathrm{C}_{4} \mathrm{H}_{9} \mathbf{P 1}, \mathrm{C}_{8} \mathrm{H}_{17} \mathbf{P 2}\right)$ have been synthesized. In addition, the new co-polymer $[-\mathrm{C} \equiv \mathrm{C}$ $\left.\mathrm{C}_{6} \mathrm{H}_{4}\left(2,5-\mathrm{OC}_{8} \mathrm{H}_{17}\right)_{2}-\mathrm{C} \equiv \mathrm{C}-\mathrm{C}_{6} \mathrm{H}_{4}\left(2,5-\mathrm{OC}_{4} \mathrm{H}_{9}\right)_{2}-\right]_{\mathrm{n}} \mathbf{P 5}$ has been prepared where different alkoxy substituents are attached to alternate arene rings along the polymer backbone. The absorption and photoluminescence spectra of the polymers, $\mathbf{P} \mathbf{1}$ and $\mathbf{P 2}$ confirmed that the lowest energy band is blue shifted by the introduction of the biphenylene groups into the alkoxy-substituted poly(ethynylenephenylene)s. The blue shift of the lowest energy band was a consequence of the loss of planarity that was evident in the X-ray structure of the model compounds.

\section{Supplementary Information}

The ${ }^{13} \mathrm{C}$ NMR spectrum of $\mathrm{C}_{6} \mathrm{H}_{5}-4-\mathrm{C}_{6} \mathrm{H}_{4}-\mathrm{C} \equiv \mathrm{C}-\mathrm{C}_{6} \mathrm{H}_{4}$ $\left(2,5-\mathrm{OC}_{8} \mathrm{H}_{17}\right)_{2}-\mathrm{C}_{6} \mathrm{H}_{4}-4-\mathrm{C}_{6} \mathrm{H}_{5} \mathrm{M} 2$; and crystal data, data collection and structure refinement for M1, M2 and $\mathrm{Me}_{3} \mathrm{SiC} \equiv \mathrm{C}\left(\mathrm{C}_{6} \mathrm{H}_{4}\right)_{2} \mathrm{C} \equiv \mathrm{CSiMe}_{3}$ are available from the Cambridge Crystallographic Data Centre via www.ccdc.cam.ac.uk/data_request/cif or from the Cambridge Crystallographic Data Centre, 12 Union Road, Cambridge CB2 1EZ, UK; fax: +44 1223336 033; or e-mail: deposit@ccdc.cam.ac.uk. The CCDC reference numbers for the three crystal structures are 997486-997488. Supplementary information is also available at www.ias.ac.in/chemsci.

\section{Acknowledgements}

We are grateful to the Leverhulme Trust and the Royal Society, UK; and Higher Education Quality Enhancement Project (HEQEP), UGC, Bangladesh for financial support (to M. Y.), Shahjalal University for study leave (to M. Y.), and the EPSRC for funding to purchase the X-ray diffractometer. The EPSRC sponsored polymer molecular weight determination service run by RAPRA is gratefully acknowledged.

\section{References}

1. Pei Q B, Yu G, Zhang C Z, Yang Y and Heeger A 1995 Science 2691086
2. Gunes S, Neugebaur H and Sariciftci N S 2007 Chem. Rev. 1071324

3. Thomas I S W, Joly G D and Swager T M 2007 Chem. Rev. 1071339

4. Mitscheke U and Bauerle P 2000 J. Mater. Chem. 10 1471

5. Burroughes J H, Bradley D D C, Brown A R, Marks R N, Mackay K, Friend R H, Burn P L and Holmes A B H 1990 Nature 347539

6. Pang Y, Li J, Jones D, Claridge J B, Loye H C Z and Bunz U H F 1999 Macromolecules 324460

7. Zhu Z and Swager M 2002 J. Am. Chem. Soc. 1249670

8. Coakley K M and Mcgehee M D 2004 Chem. Mater. 16 4533

9. Kim J, McQuade D T, McHugh S K and Swager T M 2000 Angew. Chem. Int. Ed. 393868

10. Zhang S-W and Swager T M 2003 J. Am. Chem. Soc. 1253420

11. Bunz U H F 2000 Chem. Rev. 1001605

12. Li H, Powell D R, Hayashi R K and West R 1998 Macromolecules $\mathbf{3 1} 52$

13. Ofer D, Swager T M and Wrighton M S 1995 Chem. Mater. 7418

14. Pschirer N G, Miteva T, Evans U, Roberts R S, Marshall A R, Neher D, Myrick M L and Bunz U H F 2001 Chem. Mater.13 2691

15. Bunz U H F 2009 Macromol. Rapid Commun. 30772

16. Sonogashira K 2002 J. Organomet. Chem. $\mathbf{6 5 3} 46$

17. Yamamoto T, Fang Q and Morikita T2003 Macromolecules 364262

18. Bangcuyo C G, Rampey-Vaughn M E, Quan L T, Angel S M, Smith M D and Bunz U H F 2002 Macromolecules 351563

19. Weder C and Wrington M S 1996 Macromolecules 29 5157

20. Moroni M, Moigne J L and Luzzati S 1994 Macromolecules 27562

21. Rattanatraicharoen $\mathrm{P}$, Yamabuki $\mathrm{K}$, Oishi $\mathrm{T}$ and Onimura K 2012 Polym. J. 44224

22. Bunz U H F 2001 Acc. Chem. Res. 34998

23. Younus M, Köhler A, Cron S, Chawdhury N, AlMandhary M R A, Lewis J, Long N J, Friend R H and Raithby P R 1998 Angew. Chem. Int. Ed. 373036

24. Chawdhury N, Köhler A K, Friend R H, Younus M, Long N J, Raithby P R and Lewis J 1998 Macromolecules $\mathbf{3 1} 722$

25. Long N J, White A J P, Williams D J and Younus M 2002 J. Organomet. Chem. 64994

26. Saha R, Qaium M A, Debnath D, Younus M, Chawdhury N, Sultana N, Kociok-Kohn G, Ooi L and Raithby P R 2005 Dalton Trans. 2760

27. Takahashi S, Kuroyama Y, Sonogahara K and Hagihara N 1980 Synthesis 627

28. Antonelli E, Rosi P, Sterzo C L and Viola E $1999 \mathrm{~J}$. Organomet. Chem. $\mathbf{5 7 8} 210$

29. Bao Z, Chen Y, Cai R and Yu L 1993 Macromolecules 265281

30. Errington R J 1997 In Advanced Practical Inorganic and Metalorganic Chemistry (London: Chapman and Hall)

31. Otwinowski Z and Minor W 1999 In DENZO-SMN Manual (Dallas: University of Texas Southwestern Medical Center) 
32. Altomare A, Burla M C, Camalli M, Cascarano G L, Giacovazzo C, Guagliardi A, Moliterni A G G, Polidori G and Spagna R 1999 J. Appl. Cryst. 32 115

33. Sheldrick G M 1997 SHELXL 97 Program for Crystal Structure Determination, (Germany: Universität Göttingen)

34. Farrugia L J 1997 J. Appl. Cryst. 30565

35. Pizzoferrato R, Berliocchi M, Di Carlo A, Lugli P, Venanzi M, Micozzi A, Ricci A and Lo Sterzo C 2003 Macromolecules 362215

36. Perera K P U, Krawiec M and Smith D W 2002 Tetrahedron 5810197

37. Perera K P U, Abboud K A, Smith D W and Krawiec M 2003 Acta Cryst. C 59107
38. Allen F H 2002 Acta Cryst. Sec B $\mathbf{5 8} 380$

39. Levitus M, Schmieder K, Ricks H, Shimizu K D, Bunz U H F and Garcia-Garibay M A $2001 \mathrm{~J}$. Am. Chem. Soc. 1234259

40. James P V, Sudeep P K, Suresh C H and Thomas K G 2006 J. Phys. Chem. A 1104329

41. Francke V, Mangel T and Mullen K 1998 Macromolecules $\mathbf{3 1} 2447$

42. Köhler A, Wilson J S, Friend R H, Al-Suti M K, Khan M S, Gerhard A and Bassler H 2002 J. Chem. Phys. 116 9457

43. Chawdhury N, Köhler A K, Friend R H, Wong WY, Lewis J, Younus M, Raithby P R, Corcoran T C, Al-Mandhary M R A and Khan M S 1999 J. Chem. Phys. 1104963 